\title{
Patterns of nest placement of lappet faced vulture (Torgos tracheliotos) in Lochinvar National Park, Kafue Flats, Zambia
}

\author{
Chansa Chomba $^{1^{*}}$, Eneya M'simuko ${ }^{2}$, Vincent Nyirenda ${ }^{3}$ \\ ${ }^{1}$ School of Agriculture and Natural Resources, Disaster Management Training Centre, Mulungushi University, Kabwe, Zambia; \\ *Corresponding Author: chansachomba@rocketmail.com, ritachansa@yahoo.com \\ ${ }^{2}$ School of Natural Resources, Copperbelt University, Kitwe, Zambia \\ ${ }^{3}$ Department of Research, Zambia Wildlife Authority, Chilanga, Zambia
}

Received 5 September 2013; revised 5 October 2013; accepted 13 October 2013

Copyright (C) 2013 Chansa Chomba et al. This is an open access article distributed under the Creative Commons Attribution License, which permits unrestricted use, distribution, and reproduction in any medium, provided the original work is properly cited.

\begin{abstract}
This study assessed the nesting patterns of lappet faced vulture in Lochinvar National Park, on the Kafue flats, Zambia. Road drives and foot patrols were used to identify and take GPS coordinates of lappet faced vulture nests. The main objectives of the study were: 1) to obtain basic breeding information of lappet-faced vulture in Lochinvar National Park and the Kafue Flats in general, 2) to determine size of the breeding population in the National Park, 3) to document distribution of the nesting sites, 4) to facilitate development of a monitoring programme that would secure the nesting sites from human disturbance, and 5) to determine availability of suitable nesting sites and major threats that may interfere with breeding. Tree species on which nests were found were identified and height of nest above ground was estimated. A total of 22 nests were recorded with 5 (23\%) being lappet faced vulture nests on seven species of trees. The mean height for nest placamenet was $10 \mathrm{~m}$ above ground. Host tree physiognomy, size and height were important characteristics in nest placement. Large trees of $10 \mathrm{~m}$ and above are critical in facilitating nest placement and must be protected in identified breeding sites.
\end{abstract}

Keywords: Raptors; Nest Placement; Tree Height; Lochinvar; Kafue Flats; Habitat

\section{INTRODUCTION}

Vultures are very special type of raptors. They locate carcasses by scanning the ground while soaring high in the air [1]. While they soar, they also observe each other, so that when one identifies a carcass and descends, others would follow. They are large and robustly built (Figure 1), and due to their large size, they mainly depend on soaring flight and often congregate in large numbers at a carcass. After identifying potential food, they usually perch on nearby trees to be sure that the animal is dead, and this is why it is important to have large trees with branches large enough to support their weight. From the perch, one or few brave birds will take the lead to the carcass and soon others will follow. Like other raptors, vultures are on top of the food chain and as such play an important role in the functioning of ecosystems. Regarding its size, the lappet-faced vulture is the largest of the three dark vulture species, the other two being hooded (Necrosyrtes monachus) and white headed (Aegypius occipitalis) (Figure 1). It also ranks as the longest and largest winged vulture in its range behind the closely related cinereous vulture (Aegypius monachus) [1], although some co-occurring Gyps vultures tend to be heavier on average, especially the cape vulture (Gyps coprotheres) and Eurasian griffon (Gyps fulvus). Its heavy yellowish hooked bill and bare red head with its consipicuous skin folds are a major diagnostic feature among other raptors (Figure 2).

The Lappet-faced vulture or Nubian vulture (Torgos tracheliotos) is mostly African Old World vulture belonging to order Accipitriformes, which also includes eagles, kites, buzzards and hawks, but its size and shape of beak are unmistakenly larger than other raptors (Figure 2). It is the only member of the genus Torgos. It was formerly considered monotypical, but has now been separated into two subspecies: 1) the nominate race which is found almost throughout Africa, and 2) sub- 


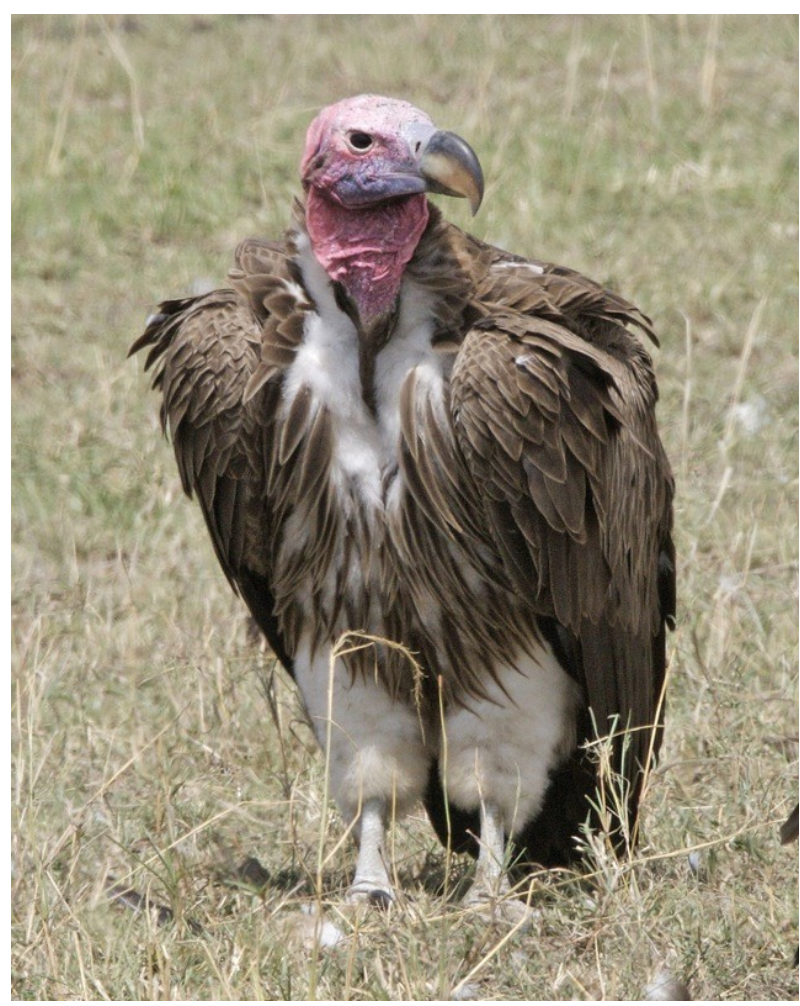

Figure 1. Lappet faced vulture (Torgos tracheliotus) is one of the largest vultures reaching about $100 \mathrm{~cm}$ (39 inches) in length, its massive size of the bird enables it to catch small mammals and some time to scare off other raptors from carrion (Source: Micrsoft Encarta 2009).

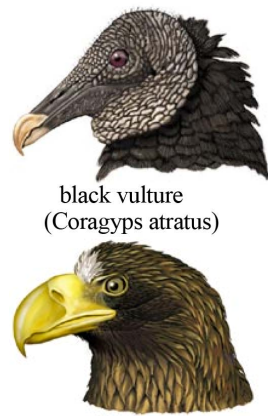

Steller's sea eagle (Haliaeetus pelagicus)

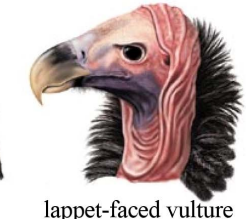

lappet-faced vulture

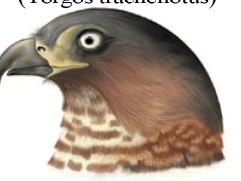

hook-billed kite (Chondrohierax uncinatus)

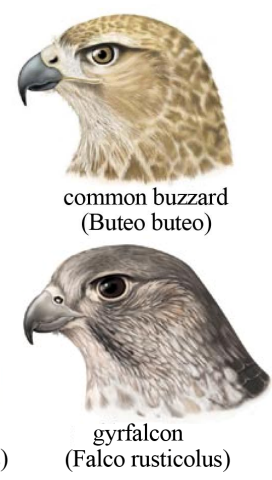

(Falco rusticolus)
Figure 2. Lappet faced vulture with bear head and massively built and hooked bill which are major diagnostic features which sets it apart in appearance from other raptors (Source: Encyclopaedia Britannica 2010).

species T. t. negevensis occurring in the Negev desert of Sinai differs considerably in appearance from African vultures [2].

The distribution of the species in Africa is intermittent being absent from much of the central and western parts of the continent and recorded to be declining elsewhere in its range. It is recorded to nest in: Senegal, Mali, Burkina Faso, Niger, Chad, Sudan, southeastern Egypt,
Ethiopia, Somalia, Kenya, Tanzania, Uganda, Rwanda, easternmost part of the Democratic Republic of the Congo, parts of Zambia, Malawi, Mozambique, Swaziland, northeastern South Africa, Zimbabwe, Botswana, Namibia, the Gambia, Guinea, Ivory Coast, Benin, the Central African Republic, southern Angola and possibly in Mauritania and Nigeria. Across the Red Sea, the species nests in Arabia, Yemen, Oman and the United Arab Emirates [2-4].

With regard to foraging, its scavenging habits of feeding on carcasses are fairly well understood. It finds its food by sight or by watching other vultures. More so than many other African vultures that find carrion on their own and start tearing through the skin. The lappet faced vulture is the most powerful and aggressive of the African vultures, and other vultures will usually cede a carcass if the Lappet-faced decides to assert itself. This is often beneficial to the less powerful vultures because, with their powerful beak, bare head and knotty muscles, they can tear through the tough hides of large mammals that the other raptors cannot penetrate (Figure 2), although hyenas (Crocuta crocuta) are more efficient in this regard. The bald head is advantageous, because a feathered head would become spattered with blood and other fluids, and thus be difficult to keep clean. However, pioneering in the opening up of carcasses before other species come in, has the potential to expose the species to mainly chemical poisoning, particularly in areas of Africa where poisonous chemicals are used in poaching of wild animals or control of livestock predators. Usually after opening the carcass, it frequently hangs around the edges of the throngs at large carcasses, waiting until the other vultures are done to feed on remnant skin, tendons and other coarse tissues that the others will not eat, which in itself, is an important feeding behavioural component that facilitates ecological separation and avoids direct competion and hence underscoring their importance in the food chain. Big game animals, up to the size of elephant (Loxodonta africana), with tough skin are preferred as carrion, since they provide the most subsistence at a sitting of up to a full crop of $1.5 \mathrm{~kg}(3.3 \mathrm{lb})$ of meat $[5,6]$.

Regarding breeding, records show that in southern Africa it takes place from May to January. Nests consist of a pile of neatly formed sticks, and are large measuring 120 - $220 \mathrm{~cm}$ (47 - 87 inches) across and $30-70 \mathrm{~cm}$ (12 28 inches) deep. They are often lined with green leaves, as well as animal hair and skins [2]. Nests are almost always placed in the main fork or top of tree species such as Acacia, Balanites and Terminalia, at 5 to $15 \mathrm{~m}$ (16 to $49 \mathrm{ft}$ ) off the ground. The clutch contains 1 or 2 eggs, which are incubated by both parents over a period of 54 to 56 days. The young fledge at 124 to 135 days old, although they can be dependent on their parents for up to an age of 1 year or more, sometimes forcing parents to 
only nest in alternate years. There is a single remarkable record of a Lappet-faced vulture pair successfully raising a white-headed vulture. The Lappet-faced Vultures do not usually breed until it is around 6 years of age [2]. Their social behaviour is that of being generally solitary birds which do not nest in cohesive colonies as do many smaller vultures, with one tree or area usually only having 1 to 2 nests in it, though sometimes up to 10 nests have been recorded in one area. The home range of a Lappet-faced Vulture is usually at least 8 to $15 \mathrm{~km}$ (5.0 to 9.3 miles) $[6,7]$.

On the aspect of distribution and population status, the species is believed to have decreased perceptibly. Declining in Sahel and several parts of their southern, northern and western distribution in Africa. The declines are almost entirely due to human activities, including disturbances from habitat destruction and cultivation, disturbances at the nesting site to which the species is reportedly quite sensitive, and ingestion of pesticides, which are usually set out for jackals (Canis spp) and other small mammalian carnivores [8]. Cattle, which have replaced natural prey over much of the range, are now often sold off, rather than abandoned, due to the proliferation of markets and abattoirs and rarely left to die and be consumed by vultures [8]. Lappet-faced vultures are also sometimes victims of direct persecution, including shooting and the use of strychnine and other poisons. In Namibia, 86 Lappet-faced vultures were poisoned at once through a group of cattle carcasses, because the farmers erroneously believed they were killing and eating the cattle. In some cases the poisoning is done by poachers, who fear the presence of vultures will alert authorities to their activities, particularly the illegal killings of protected species [8]. They are considered Vulnerable at species level, with an estimated world population of 8500 individuals [8].

With low global population estimated at 8500, and possibly 1000 pairs (almost 3000 individuals) in southern Africa [4], the species was ranked as vulnerable and put on the IUCN red data list in 2009. Breeding records for Lochinvar National Park were earlier recorded in the 1970s by Osborne [9], and no survey has since been done until 2009 when a preliminary survey was done by Tokura Wataru, Volunteer Biologist-Lochinvar National Park, [10]. This paucity of data on the species has a potential of exposing it to habitat loss and other unkown negative effects that arising from poor management of the habitat. It was for this reason that this study was undertaken to identify nesting sites and safeguard them from human disturbance.

The objectives of the study were as follows: 1) To obtain basic breeding information of Lappet-faced vulture in Lochinvar National Park and the Kafue Flats in general; 2) To determine size of the breeding population in the $\mathrm{Na}$ tional Park; 3) To document distribution of nesting sites and 4) To develop a monitoring programme that would secure and safeguard nesting sites from human disturbance.

\section{MATERIALS AND METHODS}

\section{Study Site}

The survey was undertaken in Lochinvar National Park (Figures 3(a) and (b)), mainly in the termitaria and floodplain area in the month of September 2011-2012 following the same methods used by Tokura Wataru [10]. The survey was done mostly in the open woodland or grassland and in the shrub Dichrostachys cinerea which forms sparse thicket around Chunga Camp.

Between three and five observers walked around the study site (Figure 3(b)), and searched for possible lappet-faced vulture's nesting sites. We defined the possible Lappet-face vulture's nest based on the earlier survey done by Wataru that vulture's nests are: 1) bowl-shaped, 2) built near the top of a tree, and 3) its size is larger than one meter in diameter. When a nest was located, GPS coordinates were taken, using GPS receiver (GPS60, Germin Ltd.). The tree species hosting the nest, and visual estimation of height of the tree were recorded. The nest was only recorded as belonging to lappet faced vulture when the species was physically seen on the nest. The observation was done by naked eye with an aid of $\times 10$ wide angle Bushnell binoculars. Pictures were taken using a $560 \times$ digital zoom Sony camera. Since the survey was carried out in September which is dry season, and most trees are defoliated, visility was high, making it possible for the observer to view up to $100 \mathrm{~m}$ by the naked eyes, and as far as $200 \mathrm{~m}$ with the aid of a pair of binoculars in the open woodland or grassland.

\section{RESULTS}

\subsection{Selection of Tree Species for Placement of Nests}

The nests encountered during the survey were placed on selected tree species as follows: Acacia nigrescens 5 (23\% of total), Acacia seyal 6 (27\% of total), Faidherbia albida 6 (27\% of total), Acacia gerrardii 2 ( $9 \%$ of total), Combretum imberbe 1 (5\% of total), Commiphora spp 1 (5\% of total) and one unkown species 1 (5\% of total) (Table 1). The mean height above ground for nest placemenet was $10 \mathrm{~m}$.

\subsection{Number and Location of Nests}

A total of 22 nests were found in the area surveyed. Of the 22 nests seen, lappet faced vultures were only physically seen in five $(23 \%)$ which were confirmed as their nests (Figures 4(a)-(e)). It is likely that there were more lappet vulture nests as birds may not lay and incubate eggs at the same time, or some of them may have already 


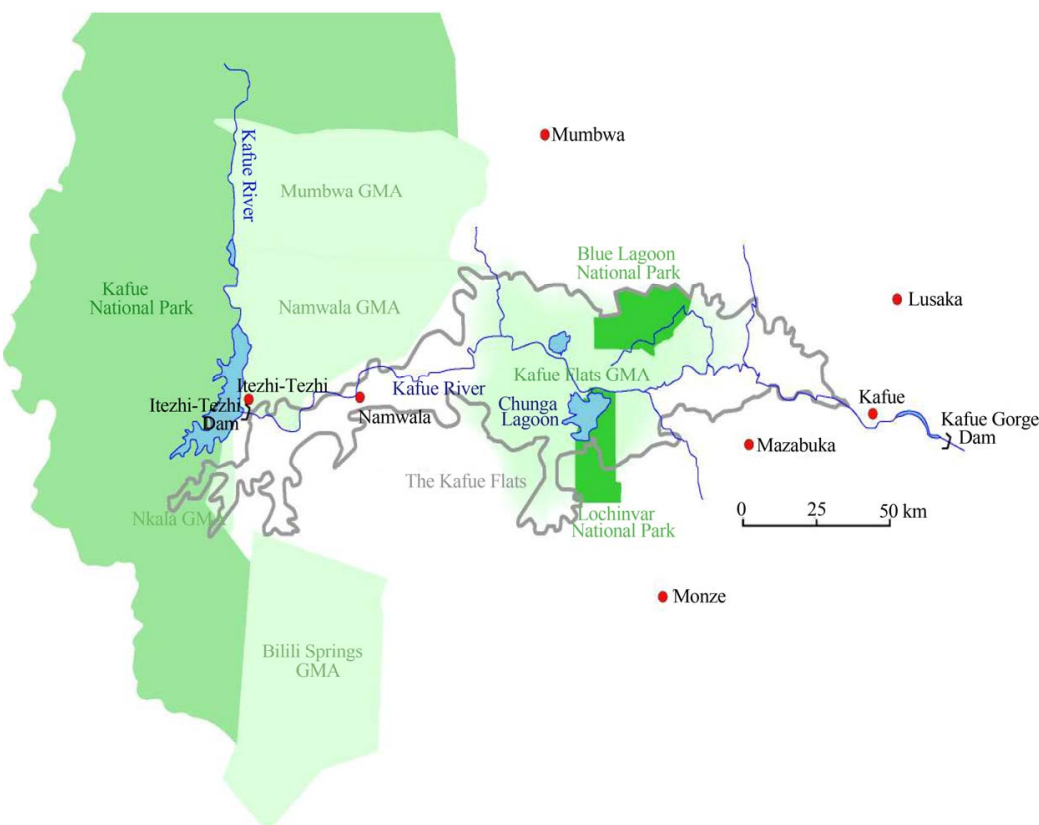

(a)

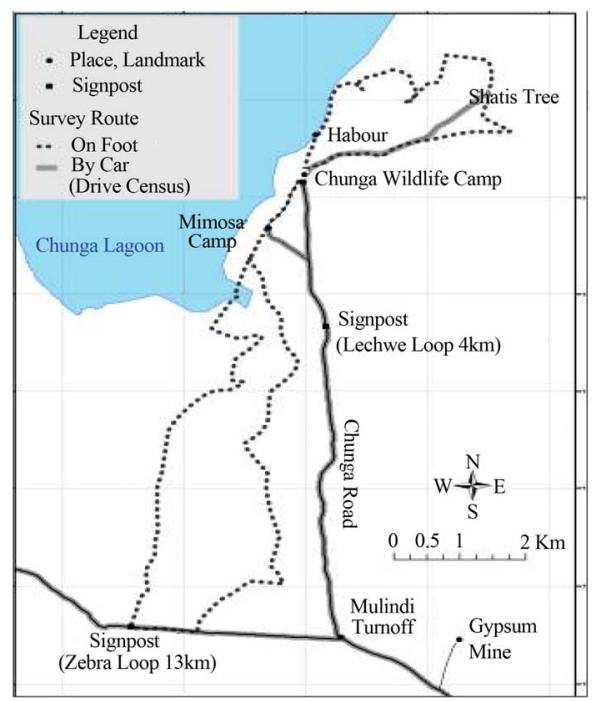

(b)

Figure 3. (a) Location of study area, Lochinvar National Park on the Kafue Flats; (b) Details of the study routes in the study area, Zambia 2012.

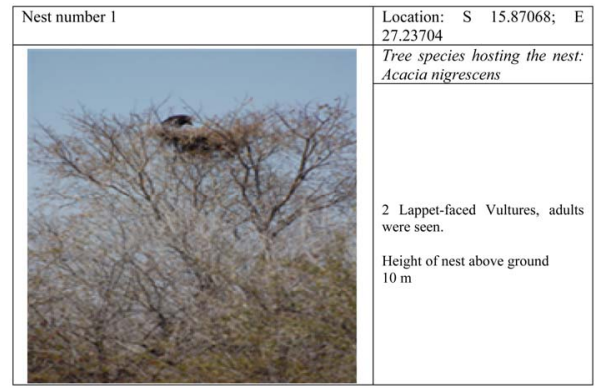

(a)

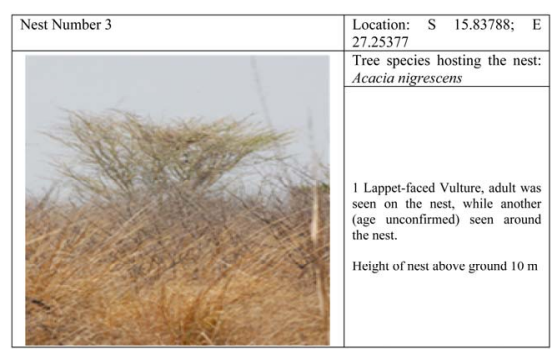

(c)

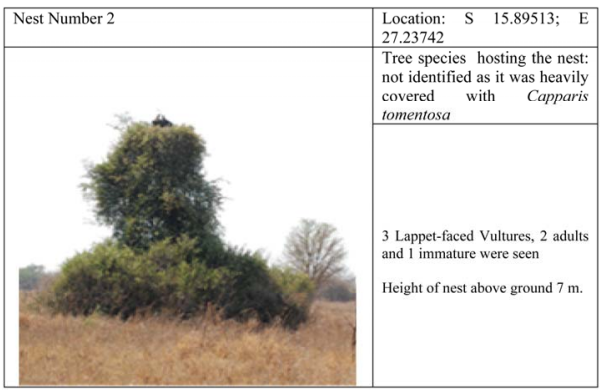

(b)

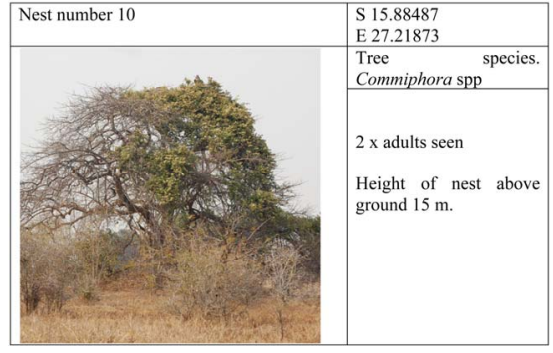

(e)

Figure 4. (a)-(e) Tree species and physiognomy of trees selected for placement of raptor nests, Lochinvar National Park, Kafue Flats, Zambia, 2012.

hatched at the time of this study.

\subsection{Nature of Vegetation Community for Nest Placement}

Nests recorded for lappet faced vulture were in the flood plain and termitaria areas of the National Park, where density of woody plant species were in fact sparse plant species was sparse. The vultures built large (Mean often more than $100 \mathrm{~cm}$ in diameter) (Table 1). Nests were made from small branches near the top of the tree (Figures 4(a)-(e)).

Regarding plant phenology; tree species were the only ones used for nest placement and not bushes, climbers, 
Table 1. Nests recorded during the survey, location, host tree species and possible species of bird, Lochinvar National Park, 2012 Zambia.

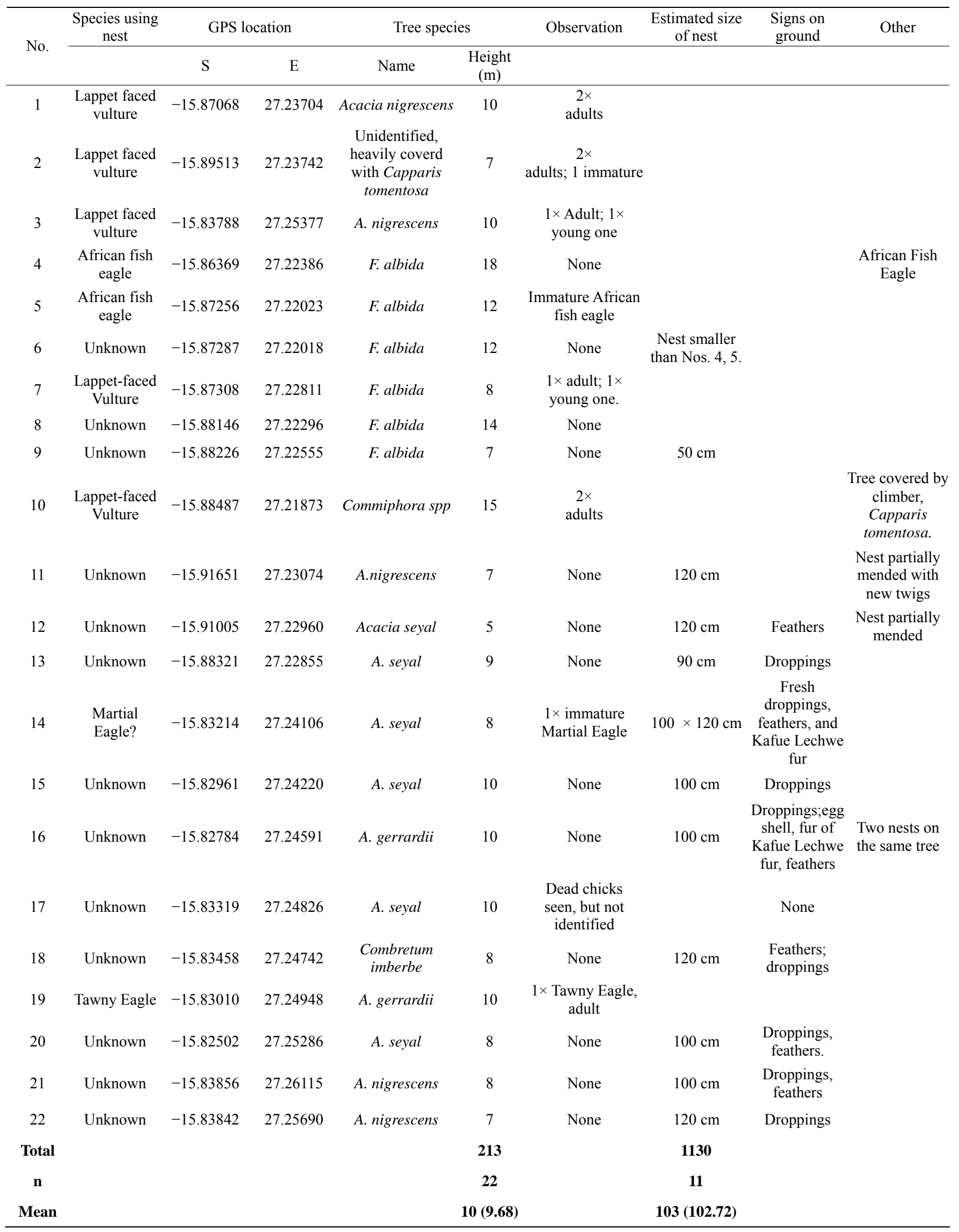


anthill tops, kopjes, or other raised features. Of the tree species used for nest placement, only three were commonly used. Placement height varied from 7 - 15 meters with overall mean of $10 \mathrm{~m}$ (Table 1). Some tall trees were however, not chosen for nest placement, probably because branches were too feeble to support the weight of a large nest and incubating pair. For instance, Acacia sieberana was very common in the study area, but no nest were built on it. The species had widely branching crown which provided no suitable folks for nest placement and nest stability during incubation.

\section{DISCUSSION}

\subsection{Size of Breeding Population in Lochinvar National Park}

In this study, potential lappet faced vulture nests were assumed to be nest numbers: 11, 12, 13, 18, 21, and 22 (Figure 4), with their physical dispersion shown in Figure 5. This is a minimum figure, as some of the remaining 17 nests in which the species were not observed could likely belong to lappet faced vulture.

Moreover, the study area did not cover the whole floodplain and termitaria zones in the National Park. Therefore, total breeding population could probably be higher than what was recorded in this study.

In the 1970s, for instance [10], eight breeding pairs were recorded in Lochinvar National Park, but such results could not be compared with the present study, because the methodology and area covered during the sur-

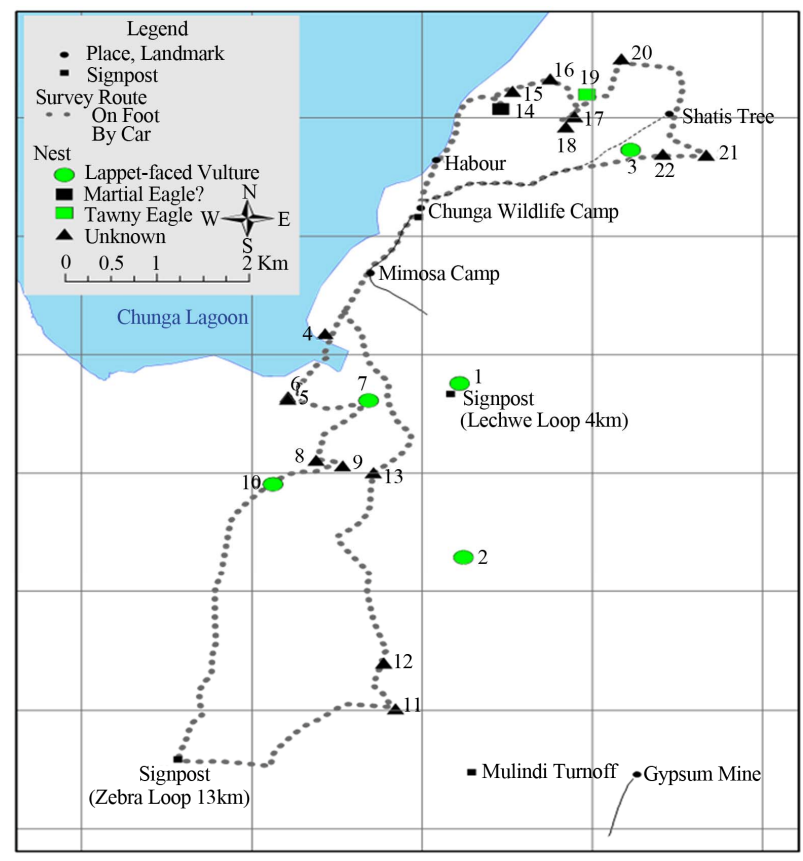

Figure 5. Physical location of active and confirmed lappet faced vulture nests and other nests in Lochinvar National Park, Kafue Flats, Zambia. vey were not indicated. Based on these estimates however, it can be stated that the breeding population of Lappet-faced vulture in Lochinvar National Park, has probably not decreased significantly since 1970s. A follow-up study would be required to draw a logical and objective conclusion on the matter.

\subsection{Monitoring Programme}

We recommend a comprehensive monitoring programme for the nesting sites to safeguard the species from further decline as it is currently classified as vulnerable under IUCN's red data list. In addition, wild ungulate populations which are the main source of food need monitoring, as their decline would also negatively affect the species. Monitoring of large trees which are the potential nesting sites should be incorporated in the Park Ecologist's routine functions. Human disturbance in potential and confirmed breeding sites should be minimized so that the birds do not abandon their nests. As earlier reported [7], tall trees of the height exceeding $10 \mathrm{~m}$ are critical for placement of raptor nests and these should be protected. Confirmed breeding sites should be zoned as low visitor use zones, because frequent and uncontrolled visitation may lead to nest abandonment. Construction of infrastructure including permanent roads should take into account the need to maintain large trees for raptor nest placements.

This study has established that mature trees $\geq 10 \mathrm{~m}$ in height in areas with minum human disturbance are critical to successful breeding of raptors on the Kafue Flats, Zambia.

\section{ACKNOWLEDGEMENTS}

We wish to thank the Regional Manager Mrs. Marina Sibbuku for allowing the researchers to operate in the National Park without interruption, Mr Wataru Tokura for initiating the survey in 2009. Mr. Benjamin Wishikoti for his skills in nest identification and other readers that contributed through constructive criticisms.

\section{REFERENCES}

[1] Oberprieler, U. and Cillie' B. (2009) The raptor guide of Southern Africa. Game Parks Publishing, Pretoria.

[2] Hardy, E. (1947) The northern lappet faced vulture in Palestine-A new record for Asia. Auk, 64, 471-472. http://dx.doi.org/10.2307/4080421

[3] BirdLife International (2007) Haliaeetus vocifer. IUCN Red List of Threatened Species. International Union for Conservation of Nature.

[4] BirdLife International (2009) Haliaeetus vocifer. IUCN Red List of Threatened Species. International Union for Conservation of Nature, Gland.

[5] Hadoram, S. (1987) Field chracaters of the Negev lappet 
faced vulture. Proccedings of the 4th International Identification Meeting, Eilat, 1-8 November 1986, 8-11.

[6] Ferguson-Lees, J. and Christie, D.A. (2001) Raptors of the world. Houghton Mifflin Company, New York.

[7] Chomba, C. and Msimuko, E. (2013) Nesting patterns of raptors; White backed vulture (Gyps africanus) and African fish eagle (Haliaeetus vocifer) in Lochinvar National Park, on the kafue flats, Zambia. Open Journal of Ecology, 3, 325-330.
[8] BirdLife International (2012) Torgos tracheliotos. IUCN 2012. IUCN Red List of Threatened Species.

[9] Leonard, P. (2005) Important bird areas in Zambia. Zambian Ornithological Society, Lusaka.

[10] ZAWA (2010) Report on the operations of the JICA Volunteer Biologist Mr. Wataru Tokura, to the Director Research. Zambia Wildlife Authority, Chilanga. Unpublished Report. 